\title{
EFEK MODERASI ORIENTASI STRATEGI ANTARA KARAKTERISTIK KEWIRAUSAHAAN TERHADAP KEBERHASILAN USAHA PARIWISATA
}

\author{
THE MODERATING EFFECT OF STRATEGY ORIENTATION \\ BETWEEN ENTREPRENEURSHIP CHARACTERISTICS \\ OF THE TOURISM BUSINESS SUCCESS
}

\author{
Fenri Abraham Stevi Tupamahu \\ Universitas Pattimura \\ f2dtupamahu@gmail.com
}

\begin{abstract}
Tourism has become one of the leading sectors in the Indonesian national economy and has become an important sector in contributing to the country's foreign exchange. This study aims to 1) identify and test the effect of entrepreneurial characteristics on the success of tourism businesses in coastal areas and small islands, 2) determine the role of strategic orientation moderation between the influence of entrepreneurial characteristics on the success of tourism businesses. This type of research is explanatory research (explanatory research) with survey methods, quantitative analysis approaches. The sample of this research is tourism business in coastal areas and small islands in Ambon City, Central Maluku Regency and Southeast Maluku Regency, Maluku Province, amounting to 40 units. Sampling using a purposive sampling technique. The criteria used in sampling are businesses that have been operating for at least five years and are individually owned businesses. Data analysis uses the statistical method of Moderated Regression Analysis. The results of this study prove that, the better the entrepreneurial characteristics that are indicated in terms of innovation, leadership, ways of making decisions, attitudes and responsibilities towards change, work effectively, efficiently, vision of the future and attitudes towards risk affect the increase in the success of tourism businesses in coastal areas and small islands in Maluku. Strategic orientation as moderation has a significant positive effect between the characteristics of entrepreneurship and the success of coastal tourism businesses and small islands in Maluku.
\end{abstract}

Keywords: Entrepreneurship Characteristics, Strategic Orientation, Business Success.

\begin{abstract}
ABSTRAK
Pariwisata telah menjadi salah satu leading sector dalam perekonomian nasional Indonesia dan menjadi sektor yang cukup penting dalam menyumbang devisa negara. Penelitian ini bertujuan untuk 1) mengidentifikasi dan menguji pengaruh karakteristik kewirausahaan terhadap keberhasilan usaha pariwisata di wilayah pesisir dan pulaupulau kecil, 2) menentukan peran moderasi orientasi strategi antara pengaruh karakteristik kewirausahaan terhadap keberhasilan usaha pariwisata. Jenis penelitian adalah penelitian penjelasan (eksplanatory research) dengan metode survey, pendekatan analisis kuantitatif. Sampel penelitian ini adalah usaha pariwisata di wilayah pesisir dan pulau-pulau kecil dalam wilayah Kota Ambon, Kabupaten Maluku Tengah dan Kabupaten Maluku Tenggara Provinsi Maluku yang berjumlah 40 unit. Pengambilan sampel menggunakan teknik purposive sampling. Kriteria yang digunakan dalam
\end{abstract}


pengambilan sampel adalah usaha yang telah beroperasi minimal lima tahun dan merupakan usaha yang dimiliki secara perseorangan. Analisis data menggunakan metode statistik Moderated Regression Analysis. Hasil penelitian ini membuktikan bahwa, semakin baik karakteristik kewirausahaan yang dindikasikan dalam hal inovasi, kepemimpinan, cara pengambilan keputusan, sikap dan tanggung jawab terhadap perubahan, bekerja efektif, efeisien, visi masa depan dan sikap terhadap resiko mempengaruhi peningkatan keberhasilan usaha pariwisata di wilayah pesisir dan pulaupulau kecil di Maluku. Orientasi strategik sebagai moderasi mempunyai pengaruh positif signifikan antara karakteristik kewirausahaan dengan keberhasilan usaha pariwisata wilayah pesisir dan pulau-pulau kecil di Maluku.

Kata Kunci : Karakteristik Kewirausahaan, Orientasi Strategik, Keberhasilan Isaha.

\section{PENDAHULUAN}

Bisnis pariwisata merupakan salah satu sektor ekonomi yang mampu tumbuh dengan pesat, dan merupakan salah satu sektor ekonomi terbesar di dunia. Pariwisata telah menjadi salah satu leading sector dalam perekonomian nasional Indonesia dan menjadi sektor yang cukup penting dalam menyumbang devisa negara.

Hasil beberapa penelitian terdahulu menjelaskan dampak kegiatan bisnis/usaha pariwisata yang ditunjang pengelolahan usaha pariwisata yang berbasis implementasi strategi bisnis, dirasakan secara langsung oleh masyarakat setempat melalui pendapatan dari penjualan berbagai barang dan jasa kepada wisatawan.

Usaha pariwisata atau industri pariwisata adalah keseluruhan usahausaha yang dapat dinikmati wisatawan semenjak awal mula proses ketertarikan untuk berwisata, menikmati lokasi daerah tujuan wisata sampai pada proses akhir wisatawan tersebut pulang menginjakkan kakinya sampai di rumah, kemudian mengenangnya.

Kementerian Perindustrian

Republik Indonesia (2018)

mengkonsepkan usaha/bisnis pariwisata meliputi bidang-bidang usaha yang dapat dikelompokan ke dalam tiga sector, antara lain (1) usaha jasa pariwisata, (2) usaha sarana pariwisata, dan (3) usaha objek pariwisata. Pengembangan usaha pariwisata secara komersil dianggap menguntungkan, dan berkontribusi dalam hal, penghapusan kemiskinan, sustainable development, pelestarian budaya (culture preservation), peningkatan ekonomi dan industri. Namun pengembangan usaha/bisnis pariwisata di Indonesia relatif bervariasi atau belum merata (cenderung berkembang pada wilayah tertentu), walaupun setiap daerah di Indonesia memiliki potensi pariwisata yang beragam, mempesona dan unik.

Provinsi Maluku memiliki garis pantai terpanjang di Indonesia dengan ragam kekayaan alam berbasis bahari potensi wisata bahari yang cukup besar dan dikenal sebagai "the spice island exotic marine paradise". Kekayaan alam ini merupakan daya tarik yang memiliki potensi yang baik untuk menjadi industri pariwisata berskala nasional maupun internasional yang dapat mendorong peningkatan ekonomi di wilayah Maluku. Sebagian besar bisnis pariwisata di Maluku mengusahakan atau berkaitan dengan wisata alam dan wisata bahari (data Dinas Pariwisata Dan Ekonomi Kreatif Provinsi Maluku tahun 2018, menjelaskan dari keseluruhan potensi wisata di daerah Maluku, terdapat 28\% 
potensi wisata alam dan $36.6 \%$ potensi wisata bahari) serta berlokasi di wilayah pedesaan, pesisir maupun pulau-pulau kecil.

Potensi ekonomi wisata alam dan wisata bahari di daerah Maluku secara umum relatif tidak sebanding dengan kondisi aktivitas bisnis/usaha pariwisata di Maluku yang cenderung secara umum belum merata berkembang dengan baik, usaha pariwisata di Maluku cenderung memiliki kelemahan antara lain, usaha pariwisata sebagian besar tergolong usaha mikro dan kecil, merupakan usaha perseorangan dan tidak terlepas kelemahan manajerial yang diasumsikan beresiko terhadap keberhasilan serta kerberlanjutan usaha. Aktivitas bisnis/usaha pariwisata di Maluku berada berlokasi di wilayah pedesaan, pesisir maupun pulau-pulau kecil yang relatif memiliki kelemahan dalam hal dukungan infrastruktur, akses dan cenderung memiliki keterbatasan kompetensi pengusaha dalam hal ilmu bisnis pariwisata maupun keterbatasan sumberdaya internal usaha dalam menyesuaikan dinamisasi lingkungan eksternal.

Aktivitas bisnis di wilayah kepulauan (wilayah pedesaan, pesisir maupun pulau-pulau kecil) cenderung memiliki perbedaan dengan aktivitas bisnis di wilayah continental. Wilayah pesisir dan pulau-pulau kecil adalah area pantai, dan gugusan pulau-pulau yang berukuran kecil, menurut UNESCO 1991 bahwa batasan pulau kecil adalah pulau dengan luas area kurang dari $2.000 \mathrm{~km}^{2}$. Batasan untuk pulau-pulau kecil memiliki jumlah penduduk kurang dari atau sama dengan 500.000 orang. Pulau-pulau kecil merupakan ekosistim terisolasi, membentuk kehidupan yang unik dan dari segi budaya masyarakat pulaupulau kecil mempunyai budaya yang umumnya berbeda dengan masyarakat pulau kontinen dan daratan.

Keterkatian secara langsung aspek-aspek ekonomi wilayah, sosial, budaya, kondisi geogrfis, kondisi iklim dalam aktivitas bisnis, relatif dipandang memperlemah daya dukung aktivitas bisnis pariwisata dan terkadang sebagai barrier aktivitas bisnis. Kondisi tersebut mendasari argument bahwa aktivitas bisnis pariwisata di wilayah pedesaan, pesisir maupun pulau-pulau kecil relatif berada dalam lingkungan bisnis, terutama lingkungan eksternal yang lebih kompleks. Keterbatasan aktivitas bisnis pariwisata di wilayah pedesaan, pesisir maupun pulau-pulau kecil, diibaratkan dalam kondisi lingkungan bisnis tidak mendukung atau tidak ramah (hostile environment), lingkungan tersebut diasumsikan peluang bisnis yang tersedia (exploitable opportunities) relatif sedikit.

Kondisi

tersebut menggambarkan ambivalensi keberhasilan bisnis pariwisata di pesisir maupun pulau-pulau kecil. Kelemahan bagi usaha kecil sektor wisata bahari di pulau-pulau kecil adalah kurangnya permodalan dan keterampilan sumberdaya manusia yang belum maksimal, sehingga kelompokkelompok usaha kecil kesulitan dalam keberlangsungan usaha.

Substansi hasil kajian Iksyaniyah (2015) menjelaskan bahwa beberapa bisnis membutuhkan input yang hanya dapat ditemukan di wilayah pedesaan, pesisir dan pulau-pulau kecil, baik dalam produksi maupun dalam bauran pemasaran, misalnya usaha berbasis kerajinan, hasil pertanian, perikanan dan pariwisata. Pendapat Iksyaniyah (2015) mendasari argumen bahwa usaha pariwisata di wilayah pesisir dan pulau-pulau kecil di Maluku walaupun dengan berbagai keterbatasan, 
diasumsikan memiliki prospek bisnis yang baik.

Kondisi lingkungan bisnis, cenderung mendasari argument bahwa kesuksesan atau keberhasilan usaha pariwisata di Maluku terutama di wilayah pesisir dan pulau-pulau kecil, merupakan pencapaian yang kompleks atau sulit. Namun wilayah pesisir dan pulau-pulau kecil di Maluku cenderung membentuk karakteristik semangat, sikap, perilaku dan kemampuan individu-individu pengusaha usaha pariwisata yang khas untuk proaktif mengeksplorasi ekosistim secara inovatif sebagai kegiatan bisnis guna memperoleh keuntungan ekonomi. Li \& Jia (2015) menjelaskan bahwa tidak semua pengusaha dapat berhasil dalam bisnis, wirausah membutuhkan karakteristik khusus untuk memungkinkan mereka sukses.

Kesuksesan atau keberhasilan usaha pariwisata di daerah Maluku, relatif tidak hanya berdasar pada keindahan alam, namun pengusaha usaha pariwisata mampu menyesuaikan, atau mengkombinasikan sumberdaya yang dimiliki, walaupun dengan kecenderungan terbatas, menunjukan semangat, kemauan yang tinggi untuk mewujudkan gagasan inovatif sebagai karakter bisnis. Kondisi tersebut merupakan gambaran karakteristik kewirausahaan yang dimiliki oleh pengusaha usaha pariwisata yang mengambarkan perilaku, sifat atau tingkah laku yang khas dalam pengelolahan usaha/operasional dan pengembangan usaha pariwisata di Maluku terutama di wilayah pesisir dan pulau-pulau kecil.

Gambaran semangat, kemauan yang tinggi untuk mewujudkan gagasan inovatif sebagai karakter bisnis dalam kondisi relatif sulit merupakan aktualisasi karakteristik kewirausahaan pengusaha usaha pariwisata di daerah
Maluku. Karakteristik kewirausahaan mengaktualisasi ciri-ciri pribadi dan keterampilan pengusaha usaha pariwisata di Maluku dalam perilaku manajemen usaha mengimplementasikan kebijakan manajemen secara efektif dan efisien. karakteristik kewirausahaan adalah suatu karakteristik yang perlu dimiliki oleh setiap wirausaha ketika menjalankan usahanya, dan sifat ini menjadi sebuah pendorong kesuksesan. Konsep karakteristik kewirausahaan menurut Abdulwahab \& Al-Damen (2015) adalah ciri-ciri pribadi dan keterampilan yang merupakan kompetensi wirausahawan yang diperlukan untuk mencapai keberhasilan.

Walaupun dihadapkan pada kondisi alam dengan beragam kesulitan, keterbatasan dan tantangan, pengusaha usaha pariwisata di Maluku memiliki daya juang, dan relatif mampu mengeksplorasi peluang bisnis, merubah diri menjadi technopreneur dan didukung perilaku action oriented. Perilaku action oriented pada prinsipnya adalah orientasi layanan yang teraktualisasi dalam pengelolahan usaha yang menitikberatkan pada orientasi pasar, orientasi pesaing dan orientasi teknologi, sebagai gambaran orientasi strategi yang diimplementasikan oleh pengusaha bisnis pariwisata di Maluku.

Dimensi-dimensi orientasi strategi terdiri dari, orientasi pelanggan, orientasi kewirausahaan, orientasi pembelajaran dan orientasi inovasi. Secara empiris Babalola (2020) membuktikan bahwa oreintasi strategi berpengaruh terhadap efektivitas perusahaan. Dalam konteks operasional oreintasi strategi pada prinsipnya merupakan arah, kebijakan yang bersifat strategis, orientasi strategis adalah arah strategis perusahaan dalam 
menciptakan perilaku yang tepat sehingga mencapai kinerja. Hasil-hasil kajian empiris, antara lain, Nuvriasari et.al (2015) dan Utaminingsih (2016), menjelaskan orientasi strategis berpengaruh positif terhadap keberhasilan usaha.

Gambaran pengelolahan usaha atau operasional usaha pariwisata di Maluku merupakan aktualisasi kombinasi atau interaksi karakteristik pengusaha dengan implementasi orientasi strategi sebagai suatu mekanisme aktivitas bisnis yang khas dan dianggap penting serta diasumkian sebagai determinan pencapaian keberhasilan usaha pariwisata di wilayah pesisir dan pulau-pulau kecil. Keberhasilan usaha pariwisata di Maluku merupakan merupakan tingkat pencapaian atau prestasi bisnis yang dicapai dalam kurun waktu tertentu.

Keberhasilan bisnis/usaha antara lain, laba/profitability, produktivitas dan efisiensi, daya saing, kompetensi dan etika usaha, serta terbangunnya citra baik (trust internal dan trust external). Keberhasilan usaha pariwisata merupakan ukuran peningkatan modal, skala usaha, laba dan peningkatan kunjungan wisatawan.

Keterkaitan aspek karakteristik kewirausahaan, orientasi strategi dan dampaknya terhadap keberhasilan usaha dikaji secara luas, dengan hasil beragam, Tehseen et.al (2015) menguatkan bukti kompetensi, karakteristik dan orientasi kewirausahaan memiliki hubungan positif dengan kinerja usaha kecil. Namun hasil kajian Obeidat (2016) membuktikan bahwa orientasi strategi tidak berpengaruh langsung terhadap kinerja perusahaan. Norzalizah et al (2017) menyimpulkan bahwa orientasi strategi berdampak positif terhadap kinerja sebagai gambaran keberhasilan perusahaan bila didukung pemerintah.
Berdasarkan karakteristik lingkungan, wilayah dan karakteristik bisnis, diasumsikan keterkaitan, kombinasi model konseptual karakteristik kewirausahaan, orientasi strategi dan dampaknya sebagai determinan keberhasilan usaha pariwisata di wilayah pesisir dan pulaupulau kecil di Maluku berbeda. Kombinasi atau keterkaitan karakteristik kewirausahaan dengan implementasi orientasi strategi sebagai suatu mekanisme aktivitas bisnis dipandang penting sebagai determinan pencapaian keberhasilan usaha. Namun hal tersebut perlu dikaji guna pembuktian secara empiris. Penelitian ini dikembangkan dalam konteks pencapaian keberhasilan usaha pariwisata di wilayah pesisir dan pulaupulau kecil.

\section{METODE PENELITIAN}

Jenis penelitian adalah penelitian penjelasan (eksplanatory research) dengan metode survey, pendekatan analisis kuantitatif. Sampel adalah usaha pariwisata di wilayah pesisir dan pulau-pulau kecil dalam wilayah Kota Ambon, Kabupaten Maluku Tenggah dan Kabupaten Maluku Tenggara Provinsi Maluku yang berjumlah 40 unit. Pengambilan sampel menggunakan teknik purposive sampling. Kriteria yang digunakan dalam pengambilan sampel adalah usaha yang telah beroperasi minimal lima tahun dan merupakan usaha yang dimiliki secara perseorangan.

Pengumpulan data mengunakan instrument kuisioner. Variabel karakteristik kewirausahaan (KK) didefinisikan sebagai karateristik/ciriciri yang menonjol dari pengusaha pariwisata dalam mengenali dan bertindak terhadap pengelolahan usaha pariwisata dan merespon peluang pasar. 


\begin{abstract}
Indikator karakteristik kewirausahan dalam penelitian ini adalah, inovasi, kepemimpinan, inovasi, cara pengambilan keputusan, dan tanggung jawab, sikap terhadap perubahan, bekerja efektif, efeisien, visi masa depan dan sikap terhadap resiko. Variabel orientasi strategi (OS) didefinisikan sebagai empat dimensi yaitu orientasi pasar, orientasi belajar, orientasi kewirausahaan dan orientasi karyawan. Variabel keberhasilan usaha (KU) pariwisata merupakan ukuran peningkatan modal, skala usaha, laba dan peningkatan kunjungan wisatawan. Pengukuran variabel menggunakan skala Likert, mulai dari skala 1 (sangat tidak setuju) sampai dengan skala 5 (sangat setuju). Model analisis dijelaskan pada gambar 1 berikut ini.
\end{abstract}

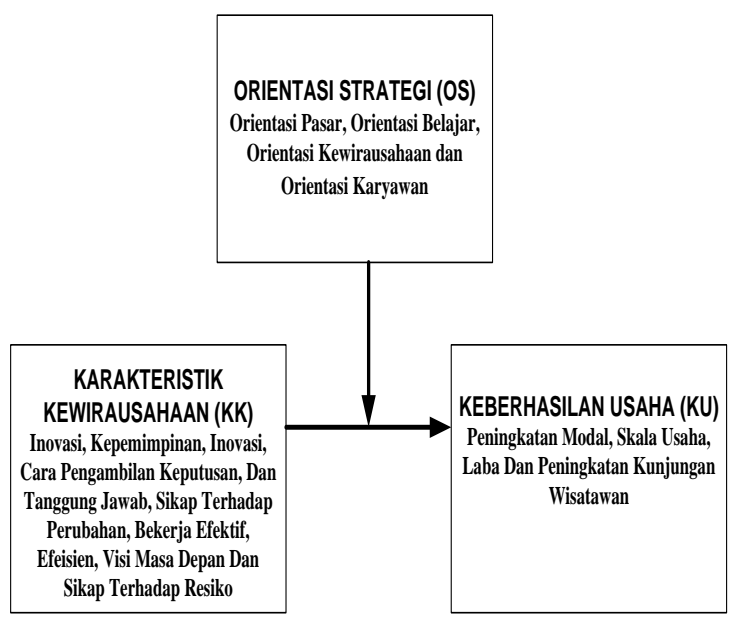

Gambar 1 Model Analisis

Analisis data menggunakan metode statistik Moderated Regression Analysis. Persamaan moderated regression adalah:

$$
\mathbf{K U}=\alpha+\beta 1 \mathrm{KK}+\beta 2 \mathrm{KK}^{*} \mathrm{OS}+\boldsymbol{\varepsilon}
$$

Keterangan:

KU = Keberhasilan usaha

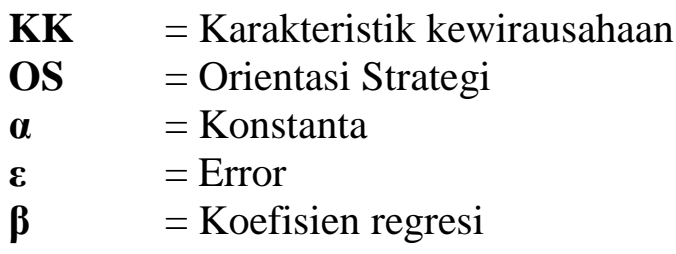

\section{HASIL DAN PEMBAHASAN}

Uji instrumen dengan menggunakan Uji validitas dan reliabilitas, membuktikan bahwa nilai nilai koefisien Product Moment ( $\mathrm{r}$ ) indikator lebih besar dari 0.5 dan nilai cronbach alpha lebih besar dari 0.6, hasil tersebut membuktikan bahwa instrumen penelitian reliabel. Uji normalitas data pada penelitian dilakukan dengan menggunakan teknik transformasi data dengan metode fungsi distribusi kumulatif yang menstandarisasi nilai residual, metode ini menggunakan uji one sampel Kolmogorov Smirnov, berdasarkan hasil uji terbukti bahwa nilai sig lebih besar dari 0.05 , hasil tersebut berarti nilai residual terstandarisasi dinyatakan menyebar secara normal, dengan demikian sebaran data dapat dikatakan berdistribusi normal.

Hasil uji regresi moderasi, menggunakan model regresi pure moderator, model ini menjelaskan variabel moderator (KK* OS) tidak berhubungan dengan variabel keberhasilan usaha (KU) dan prediktor tidak berfungsi sebagai variabel independen, namun variabel moderator (KK*OS) berinteraksi dengan variabel prediktor karakteristik kewirausahaan (KK). Hasil perhitungan regresi moderasi dapat dijelaskan pada tabel 1 berikut ini : 
Tabel 1 Hasil Analisis Regresi Moderasi

\begin{tabular}{ccccc}
\hline Variabel & $\begin{array}{c}\text { Standardized } \\
\text { Coefficients } \\
(\mathbf{B})\end{array}$ & t hitung & Sig. & Keterangan \\
\hline Constant & 1.754 & & & \\
\hline $\begin{array}{c}\text { Karakteristik } \\
\text { kewirausahaan } \\
\text { (KK) }\end{array}$ & 0.419 & 3.803 & 0.001 & Signifikan \\
\hline $\begin{array}{c}\text { Moderator } \\
\text { (KK*OS) }\end{array}$ & 0.006 & 3.000 & 0.005 & Signifikan \\
\hline R & & 0.910 & \\
\hline R Square & 0.827 \\
\hline F hitung & 88.649 \\
\hline Sign. F & 0.000 \\
\hline
\end{tabular}

Sumber : data (diolah) Tahun 2020

Persamaan moderated regression analysis berdasarkan hasil perhitungan sebagai berikut:

\section{$\mathrm{KU}=1.754+0.419 \mathrm{KK}+\mathbf{0 . 0 0 6}$ KK*OS}

Adapun interpretasi dari persamaan tersebut adalah:

1. Nilai $\beta 1=0.419$ merupakan nilai parameter atau koefisien regresi $\beta 1$ menjelaskan bahwa bertambahnya atau semakin baik variabel karakteristik kewirausahaan (KK) diindikasikan sebagai, inovasi, kepemimpinan, inovasi, cara pengambilan keputusan, sikap dan tanggung jawab terhadap perubahan, bekerja efektif, efeisien, visi masa depan dan sikap terhadap resiko, maka keberhasilan usaha pariwisata (KU) akan meningkat sebesar nilai koefisien regresi $\beta 1$, atau peningkatan keberhasilan usaha pariwisata wilayah pesisir dan pulaupulau kecil di Maluku dibutuhkan variabel karakteristik kewirausahaan sebesar 0.419 .

2. $\beta 2=0.006$ nilai parameter atau koefisien regresi $\beta 2$ menjelaskan bahwa variabel moderasi yakni orientasi strategi yang diproxi pada orientasi pasar, orientasi belajar, orientasi kewirausahaan dan orientasi karyawan mempengaruhi dalam arti mendukung atau menguatkan pengaruh variabel karakteristik kewirausahaan terhadap keberhasilan usaha pariwisata wilayah pesisir dan pulau-pulau kecil di Maluku sebesar nilai koefisien regresi $\beta 2$. Orientasi strategi menguatkan atau mendukung pengaruh variabel karakteristik kewirausahaan terhadap keberhasilan usaha pariwisata wilayah pesisir dan pulau-pulau kecil di Maluku (KU) sebesar 0.006, dengan asumsi variabel bebas yang lain tetap.

3. Nilai "r" sebesar 0.910 nilai ini membuktikan hubungan (korelasi) antara variabel karakteristik kewirausahaan dan dampak variabel moderasi terhadap keberhasilan usaha pariwisata wilayah pesisir dan pulau-pulau kecil di Maluku (KU) sebesar 91\%. nilai " $\mathrm{r}$ " " sebesar 0.827, nilai ini menjelaskan determinasi variabel karakteristik kewirausahaan dan dampak variabel moderasi terhadap keberhasilan usaha pariwisata wilayah pesisir dan pulau-pulau kecil di Maluku sebesar $82.7 \%$, sedangkan $17.3 \%$ dijelaskan 
oleh faktor lain yang tidak dijelaskan dalam model.

Guna membuktikan apakah variabel bebas mempunyai pengaruh yang signifikan terhadap variabel terikat serta dampak interaksi variable moderasi, maka dilakukan uji hipotesis dengan metode uji nilai Sig. Tabel 2 menjelaskan hasil uji hipotesis pada signifikansi $5 \%$ atau $\alpha=0,05$.

Tabel 2 Hasil Pengujian Hipotesis

\begin{tabular}{lccc}
\hline \multicolumn{1}{c}{ Hipotesis } & Nilai T Statistik & Nilai Sig & Keterangan \\
\hline $\begin{array}{l}\text { Karakteristik kewirausahaan } \\
\text { berpengaruh terhadap keberhasilan } \\
\text { usaha pariwisata wilayah pesisir dan } \\
\text { pulau-pulau kecil di Maluku. }\end{array}$ & 3.803 & 0.001 & Hipotesis Diterima \\
\hline $\begin{array}{l}\text { Terdapat pengaruh positif dari } \\
\text { orientasi strategik terhadap } \\
\text { hubungan antara karakteristik } \\
\text { kewirausahaan dengan keberhasilan } \\
\text { usaha pariwisata wilayah pesisir dan } \\
\text { pulau-pulau kecil di Maluku. }\end{array}$ & 3.000 & 0.000 & Hipotesis Diterima \\
\hline $\begin{array}{l}\text { Sumber : data (diolah) Tahun 2020 } \\
\text { nam }\end{array}$ & & &
\end{tabular}

Sumber : data (diolah) Tahun 2020

Penjelasan pengujian hipotesis untuk masing masing hipotesis menggunakan pengujian nilai $\rho$ atau kriteria signifikan pada level 0.05 , pengujian hipotesis dijelaskan berikut ini.

\section{Variabel}

\section{Kewirausahaan (KK)}

Variabel

Karakteristik

kewirausahaan (KK) memiliki nilai $\mathrm{t}$ statistik/hitung sebesar 3.803, dan nilai $\rho$ sebesar 0.001 atau signifikan pada level $0.05(\rho<0.05)$. Hasil uji hipotesis mengandung makna analisis yakni, terima Ha dan tolak $\mathrm{H} 0$ atau Hipotesis diterima. Hasil uji hipotesis ini memperlihatkan atau membuktikan bahwa variabel karakteristik kewirausahaan berpengaruh nyata atau secara signifikan terhadap keberhasilan usaha pariwisata wilayah pesisir dan pulau-pulau kecil di Maluku.

\section{Variabel Moderasi (KK*OS)}

Variabel moderasi (KK*OS) memiliki nilai t statistik/hitung sebesar
3.000, dan nilai $\rho$ sebesar 0.000 atau signifikan pada level 0.05 ( $\rho<0.05)$. Hasil uji hipotesis mengandung makna analisis yakni, terima $\mathrm{Ha}$ dan tolak $\mathrm{H} 0$ atau Hipotesis diterima. Hasil ini membuktikan bahwa secara signifikan variabel orientasi strategik sebagai moderator terhadap hubungan variabel karakteristik kewirausahaan terhadap keberhasilan usaha pariwisata wilayah pesisir dan pulau-pulau kecil di Maluku.

\section{Orientasi Strategi Sebagai Moderating Antara Karakteristik Kewirausahaan Terhadap Keberhasilan Usaha Pariwisata}

Hasil penelitian membuktikan bahwa karakteristik kewirausahaan berpengaruh terhadap keberhasilan usaha pariwisata wilayah pesisir dan pulau-pulau kecil di Maluku. Karakteristik kewirausahaan yang dindikasikan dalam hal inovasi, kepemimpinan, cara pengambilan keputusan, sikap dan tanggung jawab terhadap perubahan, bekerja efektif, efeisien, visi masa depan dan sikap terhadap resiko terbukti mempengaruhi 
keberhasilan usaha pariwisata wilayah pesisir dan pulau-pulau kecil di Maluku. Hasil penelitian ini membuktikan bahwa semakin baik karakteristik kewirausahaan yang dimiliki oleh pengusaha mempengaruhi peningkatan keberhasilan usaha pariwisata di wilayah pesisir dan pulaupulau kecil. Hasil penelitian ini mengungkapkan aspek ciri individu dalam hal semangat, sikap, perilaku dan kemampuan seseorang pengusaha usaha pariwisata yang khas sebagai basis atau yang mendasari eksplorasi, eksploitasi kreativitas dan inovasi terbukti sebagai pendorong keberhasilan usaha pariwisata di wilayah pesisir dan pulaupulau kecil.

$$
\text { Hasil }
$$

penelitian mengungkapkan, aspek kepribadian personal atau ciri pribadi dan ciri keterampilan pengusaha yang mendasari karakter pengelolahan bisnis yang khas dapat menetralisir atau meminimalkan barrier aktivitas bisnis sebagai dampak tantangan lingkungan eksternal. Dinamika, tantangan maupun keterbatasan daya dukung wilayah pesisir dan pulau-pulau kecil yang cenderung dijustifikasi sebagai lingkungan bisnis tidak mendukung atau tidak ramah (hostile environment), terbukti dapat dinetralisir melalui perilaku, sifat atau tingkah laku yang khas dalam pengelolahan usaha/operasional dan pengembangan usaha pariwisata sebagai karakter penerapan kreativitas dan inovasi untuk memecakan masalah dan memanfaatkan peluang yang teraktualisasi dalam hal inovasi, kepemimpinan, cara pengambilan keputusan, sikap dan tanggung jawab terhadap perubahan, bekerja efektif, efeisien, visi masa depan dan sikap terhadap resiko, karakteristik kewirausahaan tersebut terbukti mempengaruhi peningkatan modal, skala usaha, laba dan peningkatan kunjungan wisatawan.

Hasil penelitian Li \& Jia (2015), Aditya (2015); Norzalizah at.al (2017) dan Lee (2017) yang menyimpulkan bahwa karakteristik kewirausahaan memiliki pengaruh terhadap keberhasilan usaha.

Hasil penelitian membuktikan bahwa orientasi strategik sebagai moderasi mempunyai pengaruh positif signifikan antara karakteristik kewirausahaan dengan keberhasilan usaha pariwisata wilayah pesisir dan pulau-pulau kecil di Maluku. Orientasi strategi dalam hal orientasi pasar, orientasi belajar, orientasi kewirausahaan dan orientasi karyawan terbukti sebagai interaksi mempunyai pengaruh positif dan signifikan pada pengaruh karakteristik kewirausahaan terhadap keberhasilan usaha pariwisata di wilayah pesisir dan pulau-pulau kecil. Orientasi strategi dalam hal orientasi pasar, orientasi belajar, orientasi kewirausahaan dan orientasi terbukti secara positif memiliki efek interaksi penting dan mendukung serta memperkuat pengaruh karakteristik kewirausahaan terhadap keberhasilan usaha pariwisata di wilayah pesisir dan pulau-pulau kecil dalam hal peningkatan modal, skala usaha, laba dan peningkatan kunjungan wisatawan.

Orientasi strategi tidak secara langsung berpengaruh terhadap usaha pariwisata wilayah pesisir dan pulaupulau kecil di Maluku, namun terbukti sebagai moderasi atau dampaknya sebagai pengguat pengaruh karakteristik kewirausahaan terhadap keberhasilan usaha. Hasil penelitian ini relatif bertolak belakang dengan hasil kajian Norzalizah et.al (2017) yang menjelaskan orientasi strategi berdampak positif terhadap kinerja perusahaan dan dukungan pemerintah sebagai variabel moderasi. 
Mayoritas usaha pariwisata wilayah pesisir dan pulau-pulau kecil di Maluku merupakan usaha mikro dan usaha kecil, memformulasikan dan implementasi strategi bisnis secara non formal, sehingga orientasi strategi tidak berperan sebagai variabel yang mempengatuhi keberhasilan usaha secara langsung, namun orientasi strategi berperan mendinamisasi karakter pengusaha menjadi aksi strategis dalam pengelolahan usaha. Orientasi strategi sebagai pendorong usaha pariwisata menemukan solusi masalah yang dihadapi, mendasari terbentuk jaringan bisnis dan melengkapi kemampuan untuk menetralisir atau meminimalkan barrier aktivitas bisnis sebagai dampak tantangan, keterbatasan lingkungan wilayah pesisir dan pulau-pulau kecil. Peran moderasi orientasi strategi tidak secara langsung mempengaruhi keberhasilan usaha, namun sebagai interaksi yang mendukung aktualisasi ciri-ciri pribadi, karakter dan keterampilan pengusaha menjadi perilaku bisnis atau pengelolahan usaha yang strategis, temuan penelitian ini relevan dengan hasil kajian Obeidat (2016).

Dampak implementasi orientasi strategi bagi usaha pariwisata wilayah pesisir dan pulau-pulau kecil di Maluku adalah terbentuk patron aktivitas bisnis atau dasar formulasi strategi yang memandu arah bagi pencapaian keberhasilan usaha yang lebih baik. Penelitian ini menegaskan peran implementasi orientasi strategi bagi usaha pariwisata di wilayah pesisir dan pulau-pulau kecil yakni mengkombinasikan atau mengintegrasikan kesesuaian lingkungan internal dengan lingkungan eksternal sebagai mekanisme pengelolahn bisnis yang sesuai dan fit.
Orientasi strategi merupakan metode atau cara mendasar bagi usaha pariwisata wilayah pesisir dan pulaupulau kecil di Maluku yang memiliki keterbatasan (carryng capacity) dan tantangan untuk beradaptasi dengan dinamika lingkungan eksternalnya.

Orientasi strategi berperan sebagai gabungan keguanaan atau konfigurasi sumberdaya yang dimiliki oleh usaha pariwisata wilayah pesisir dan pulau-pulau kecil di Maluku yang bersifat mendukung atau saling melengkapi dan mendorong pencapaian keberhasilan usaha. Hasil penelitian menjelaskan bahwa orientasi strategi berperan menguatkan atau mendukung keterkaitan karakteristik kewirausahaan terhadap keberhasilan usaha. Hasil penelitian ini menjelaskan kesesuaian keterkaitan, kombinasi atau interaksi karakteristik kewirausahaan, orientasi strategi merupakan model empiris determinan keberhasilan usaha pariwisata di wilayah pesisir dan pulaupulau kecil di Maluku.

\section{PENUTUP}

\section{Kesimpulan}

Karakteristik kewirausahaan yang dindikasikan dalam hal inovasi, kepemimpinan, cara pengambilan keputusan, sikap dan tanggung jawab terhadap perubahan, bekerja efektif, efeisien, visi masa depan dan sikap terhadap resiko mempengaruhi keberhasilan usaha pariwisata di wilayah pesisir dan pulau-pulau kecil daerah Maluku. Ciri individu dalam hal semangat, sikap, perilaku dan kemampuan seseorang pengusaha usaha pariwisata yang khas sebagai basis atau yang mendasari eksplorasi, eksploitasi kreativitas dan inovasi merupakan pendorong keberhasilan usaha pariwisata di wilayah pesisir dan pulaupulau kecil. Semakin baik karakteristik kewirausahaan yang dimiliki oleh 
pengusaha mempengaruhi peningkatan keberhasilan usaha pariwisata di wilayah pesisir dan pulau-pulau kecil.

Orientasi strategi dalam hal orientasi pasar, orientasi belajar, orientasi kewirausahaan dan orientasi karyawan terbukti sebagai interaksi mempunyai pengaruh positif signifikan pada pengaruh karakteristik kewirausahaan terhadap keberhasilan usaha pariwisata di wilayah pesisir dan pulau-pulau kecil. Peran moderasi orientasi strategi tidak secara langsung mempengaruhi keberhasilan usaha, namun terbukti sebagai interaksi yang mendukung aktualisasi ciri-ciri pribadi, karakter dan keterampilan pengusaha menjadi perilaku bisnis atau pengelolahan usaha yang strategis yang merupakan determinan keberhasilan usaha pariwisata di wilayah pesisir dan pulau-pulau kecil. Kesesuaian keterkaitan, kombinasi atau interaksi karakteristik kewirausahaan, orientasi strategi merupakan model empiris determinan keberhasilan usaha pariwisata di wilayah pesisir dan pulaupulau kecil di Maluku.

\section{Saran}

Pengusaha usaha pariwisata di wilayah pesisir dan pulau-pulau kecil perlu menyesuaikan, menguatkan karakteristik kewirausahaan serta mengkombinasikan dengan orientasi strategi dalam akualisasi perilaku bisnis yang efektif sebagai budaya organisasi. Usaha pariwisata di wilayah pesisir dan pulau-pulau kecil senantiasa membangun jaringan sosial dalam hal bisnis terutama dengan Badan Usaha Milik Desa sebagai garansi dinamisasi serta keberlanjutan aktivitas bisnis di wilayah pesisir dan pulau-pulau kecil. Perlu adanya perhatian khusus dan dukungan instansi terkait khususnya pihak Pemda Maluku bagi usaha pariwisata di wilayah pesisir dan pulau- pulau kecil melalui program menguatkan kompetensi interpersonal serta penguatan karakteristik kewirausahaan pengusaha dan manajemen strategi guna mendukung pencapaian keberhasilan usaha berkelanjutan.

\section{DAFTAR PUSTAKA}

Abdulwahab M., H \& Al-Damen R., A (2015). The Impact of Entrepreneurs' Characteristics on Small Business Success at Medical Instruments Supplies Organizations in Jordan, International Journal of Business and Social Science, 6(8)

Aditya A.,D.,R. (2015). Pengaruh Moderenitas Sikap

Kewirausahaan Terhadap Keberhasilan UMKM Tempe dan Tahu di Kabupaten Bogor. Jurnal Forum Agribisnis, 5(1)

Babalola, S.,S. (2020). Role Of Organizational Strategy And Entrepreneurial Orientation On Organizational Effectiveness, International Journal of Entrepreneurship, 24(1)

Iksyaniyah, N. (2015). Pengaruh Lokasi Usaha Terhadap Keberhasilan Usaha Pedagang Kaki Lima Di Pasar Baru Krian Sidoarjo. ejournal.unesa.ac.id. 3(3)

Lee, J. (2017) The Impact of Entrepreneurs' Characteristics on the Performance of Venture Businesses. Martin School of Public Policy and Administration Graduate Capstone.

Li, X., and Jia, Y. (2015). Characteristics Influence for Entrepreneurship Behavior Ability. In International Conference on Education, Management, Commerce and 
Society (EMCS-15). Atlantis Press:614-619.

Norzalizah, B., Juhaini, J., \& Ahmad, R.,Y. (2017). Malaysian Women Entrepreneurial Characteristics, Strategic Orientation And Firm Performance: The Moderator Role Of Government Support Programs, International Journal of Advanced and Applied Sciences, 4(12), 257-262.

Nuvriasari, A., Gumirlang, W \& Sumiyarsih. (2015), Peran Orientasi Pasar, Orientasi Kewirausahaan Dan Strategi Bersaing Terhadap Peningkatan Kinerja UKM, Ekuitas: Jurnal Ekonomi dan Keuangan, 19(2), $241-259$.

Obeidat, B.,Y. (2016). The Effect of Strategic Orientation on Organizational Performance: The Mediating Role of Innovation, Int. J. Communications, Network and System Sciences, 9(2), 478-505.

Tehseen S., Sajilan S., T., Ramayah. K., G. (2015). An Intra-Cultural Study of Entrepreneurial Competencies and SMEs Business Success in Whole Sale and Retail Industries of Malaysia: A Conceptual Model. Integr. Bus. Econ. Research. 4(3).

Utaminingsih, A. (2016). Pengaruh Orientasi Pasar, Inovasi, Dan Kreativitas Strategi Pemasaran Terhadap Kinerja Pemasaran Pada UKM Kerajinan Rotan Di Desa Teluk Wetan, Welahan, Jepara. 